\title{
Maria Hsia Chang, Falungong, secte chinoise, Un défi au pouvoir
}

Paris, CERI/Autrement, 2004, 181 p.

Benoît Vermander

\section{OpenEdition}

\section{Journals}

Édition électronique

URL : http://journals.openedition.org/chinaperspectives/533

DOI : $10.4000 /$ chinaperspectives.533

ISSN : 1996-4617

\section{Éditeur}

Centre d'étude français sur la Chine contemporaine

Édition imprimée

Date de publication : 1 octobre 2005

ISSN : 2070-3449

\section{Référence électronique}

Benoît Vermander, " Maria Hsia Chang, Falungong, secte chinoise, Un défi au pouvoir », China

Perspectives [En ligne], 61 | september-october 2005, mis en ligne le 18 décembre 2006, consulté le 24 septembre 2020. URL : http://journals.openedition.org/chinaperspectives/533 ; DOI : https://doi.org/ 10.4000/chinaperspectives.533

Ce document a été généré automatiquement le 24 septembre 2020

(c) All rights reserved 


\title{
Maria Hsia Chang, Falungong, secte chinoise, Un défi au pouvoir
}

Paris, CERI/Autrement, 2004, 181 p.

\author{
Benoît Vermander
}

\section{NOTE DE L'ÉDITEUR}

Translated from the French original by Nick Oates

1 This book by Maria Hsia Chang presents itself as a summarisation of a movement that has by now become well known : the Falun Gong. ${ }^{1}$. It is divided into five chapters, the first of which essentially relates the protests of April 1999 and the repression that followed until around the end of 2001. It deals much more swiftly with what went before (the formation and the expansion of the movement) and with what has followed since then. The second chapter retraces the history of millenarian movements in China, without for all that establishing a precise link with the Falun Gong affair. The next chapter offers a detailed and thoughtful reading of the doctrine of Li Hongzhi. We should note, however, that, contrary to the indication contained in the title of the chapter, while it does examine the "beliefs", the "practices" of the movement are not studied in themselves-the possible deviation between beliefs and practices would, however, be an interesting element in understanding the movement. Parallel to this analysis, the following chapter examines the discourse of the authorities and the fundamental accusations that they direct at the Falun Gong. Finally, the last chapter situates the movement in the context of the protest movements that have emerged in China in recent years and of Chinese policy towards religious groups in general.

2 The book is soundly informed, easy to read, precise on the reported facts and generally balanced in its judgments. However, as it deals with a movement that will henceforth be the subject of much study, one may have been entitled to expect something else. This is a factual recall, not an attempt at explanation. The reader will not really understand how and why this specific group has taken on the reach that it has. The 
question of ambiguous relations rooted from the beginning within certain sectors of the Communist Party is hardly touched upon. The exact relationship with the changes that have occurred in China's socio-economic structure is also barely hinted at (few elements discuss the geographical scope of the movement).

3 Even on the factual level, the reader is entitled to hope for more: quid the internationalisation of the movement after the crackdown, for example? Will that change the nature of the Falun Gong? Will it have a direct impact on China? And in what way has the emergence of the Falun Gong redefined the religious and ideological policies of the powers-that-be, as well as their understanding of the leading role of the Party when it comes to the definition of "spiritual civilisation" ? Finally, the analysis of the social contradictions from which China suffers today is highly fragmented and consists above all in the collection of a bundle of opinions.

4 In short, the work remains ad hoc and would already require updating. Nevertheless, at a time when popular protests seem to be gaining new vigour, the adventure of the Falun Gong remains topical, and any attempt to contribute to our knowledge and an explanation of the movement will be valuable in following the developments that are underway.

\section{NOTES}

1. The original work is entitled : Falun Gong, the End of Days, Yale University Press, 2004. The French translation is by Geneviève Brzustowski. 